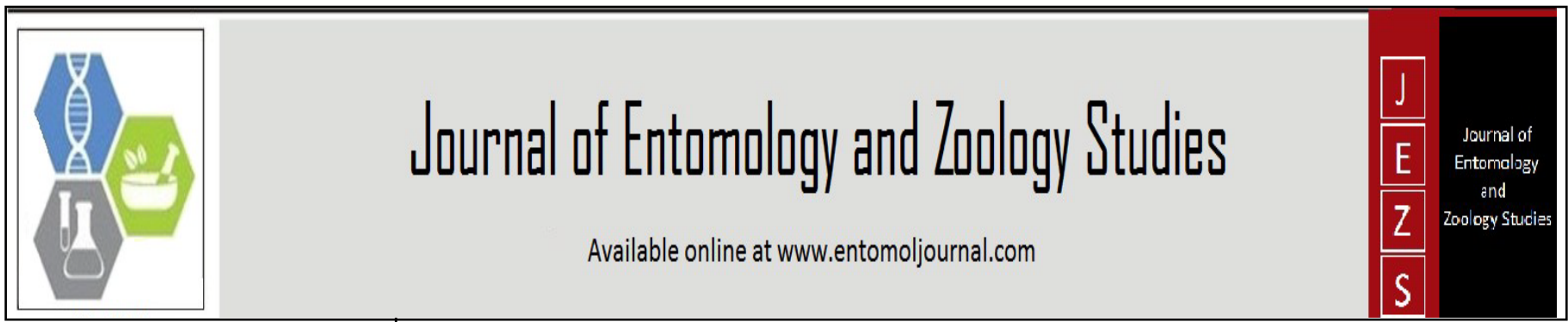

E-ISSN: 2320-7078

P-ISSN: 2349-6800

www.entomoljournal.com

JEZS 2021; 9(1): 2027-2029

(C) $2021 \mathrm{JEZS}$

Received: 03-10-2020

Accepted: 04-12-2020

\section{AR Ninu}

Department of Veterinary

Surgery and Radiology,

Veterinary College and Research

Institute, Tirunelveli, Tamil

Nadu Veterinary and Animal

Sciences University, Tamil

Nadu, India

\section{S Kokila}

Department of Veterinary

Surgery and Radiology,

Veterinary College and Research

Institute, Tirunelveli, Tamil

Nadu Veterinary and Animal

Sciences University, Tamil

Nadu, India

\section{Vishnugurubaran}

Department of Veterinary

Surgery and Radiology,

Veterinary College and Research

Institute, Tirunelveli, Tamil

Nadu Veterinary and Animal

Sciences University, Tamil

Nadu, India

\section{Teat fistula in Goats- A report of four cases}

\section{AR Ninu, S Kokila and D Vishnugurubaran}

DOI: https://doi.org/10.22271/j.ento.2021.v9.i1ac.8431

\section{Abstract}

The paper reports teat fistula and its surgical repair in four goats. Four goats with teat fistula following full thickness lacerated teat wound were presented to the surgery unit of VCC, VCRI, Tirunelveli and were operated under $2 \%$ lignocaine anaesthesia by ring block. Suturing of the fistula was done in three layers after debridement. The mucosa was sutured alone in one layer, whereas muscularis and connective tissues were sutured in the second layer by simple continuous pattern with polyglycolic acid 3-0. The skin wound was sutured by simple interrupted pattern using polypropylene 2-0. All the cases recovered successfully.

Keywords: Goat, lacerated wound, surgical repair, teat fistula

\section{Introduction}

Teat fistula is a condition where there is an abnormal tract connecting the teat cistern to the skin with leakage of milk in lactating animals ${ }^{[3]}$. If the condition is neglected it may result in mastitis. Teat fistula may be seen as a congenital or acquired condition. Acquired teat fistulas often result from full thickness teat wound or as a complication to thelotomy closure ${ }^{[4]}$. In acquired teat fistula, the affected animals may avoid milk suckling by the young ones due to pain. This in turn will have an indirect effect on the growth of the young ones. Since the condition affects the economic output of the farmer by the direct effect due to leakage of milk and indirect effect on the growth of the young one and ensuing mastitis, teat fistula may be considered as an emergency surgical condition. The incidence of teat fistula was 9.61 percentage in comparison to other teat and udder affections in goats ${ }^{[2]}$. The vulnerability of teat to injuries in goat may be attributed to its peculiar pendulous structure and anatomical location ${ }^{[1]}$. Though there are many reports on teat fistula in cows, the same on goats is comparatively lesser. This case reports the successful treatment of teat fistulas in four she goats presented with acquired teat fistula during lactation.

\section{Case history and clinical examination}

All the four cases were presented in lactation period and was considered for emergency surgery.

Case I: A one-and-a-half-year-old nondescript doe was presented with a full thickness lacerated wound on the left teat due to barbed wire that occurred within a time span of 12 hours (Fig. 1).

Case II: A two-and-a-half-year-old Salem black doe brought with a full thickness teat laceration on right teat that resulted from injury by thorn that occurred within 12 hours (Fig. 3.).

Case III: A four-year-old Kodi breed doe presented after 4 days of full thickness lacerated wound on the right teat due to injury caused by barbed wire on fencing. There was suture dehiscence after five days and re-suturing was done (Fig. 5.).

Case IV: A one and a half year Salem black doe was brought with a full thickness lacerated wound in the left teat with milk leakage that occurred about 12 hours back due to barbed wire (Fig. 7).

\section{Treatment}

Treatment was initiated by passage of a teat catheter and drainage of complete milk followed by administration of ring block at the base of the teat with $2 \%$ lignocaine solution. A custom made teat tube (infant feeding tube) was inserted prior to wound debridement and suturing.
Corresponding Author:

Department of Veterinary

Surgery and Radiology,

Veterinary College and Research

Institute, Tirunelveli, Tamil

Nadu Veterinary and Animal

Sciences University, Tamil

Nadu, India 
The wound edges were debrided minimally and sutured in three layers with mucosa alone in the first layer, muscles and connective tissue in the second layer and skin in the third layer all in simple continuous pattern except skin that was sutured in a simple interrupted pattern. Polyglycolic acid 3-0 was used for suturing first two layers and polypropylene 2-0 in third layer of suture. Post-operatively broad spectrum antibiotics for five days and analgesics for three days were used in all cases. The test tube was secured in place with an adhesive tape. Case III had suture dehiscence after five days and was re-operated. During re-surgery, in case III, a double layer of simple continuous suture pattern for mucosa, muscles and connective tissue in first layer and skin using simple interrupted pattern was employed. The test tube was replaced after three days interval. All the cases had a successful recovery.

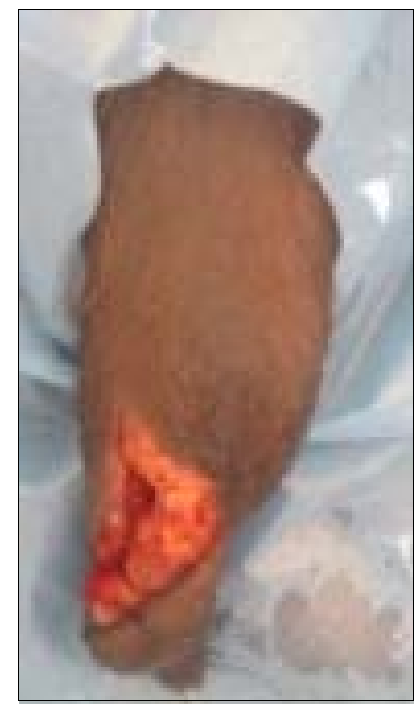

Fig 1: Pre-operative appearance of teat fistula in case I

\section{Results and discussion}

Teat fistula is considered as an emergency situation especially during lactation as the nutrient rich milk outflow can lead to mastitis resulting in economic losses to the farmer. The immediate repair of teat fistula within 12 hours will give good results ${ }^{[5]}$. After 12 hours, there will be swelling of the wound edges and repair during this time is to be undertaken after the swelling subsides for which a waiting period of two to three days may be needed. The analgesia for the surgical repair of teat fistula may be obtained by a ring block with $2 \%$ lignocaine at the base of the teat or using an inverted $\mathrm{V}$ shaped block along the edges of the teat wound. According to the author's opinion, the debridement of the wound edges should be kept minimal in lacerations with loss of tissues and in goats with small sized teat ${ }^{[6,8]}$. The most commonly recommended suture pattern is simple continuous pattern in a double row, first involving the mucosa alone and second involving the muscularis and the connective tissue. The suture materials mostly recommended for closure of the mucosa, muscularis and connective tissue are synthetic absorbable suture materials like polyglactin 910, polyglycolic acid or polydioxanone. Skin is usually sutured by non-absorbable sutures $[7,9,10]$. The use of $\mathrm{N}$ - butyl cyanoacrylate over the suture line after suturing the skin also has been reported ${ }^{[10]}$. Very good apposition of the wound edges resulted after the reconstructive surgery in all the four cases (Fig. 2, Fig. 4., Fig. 6. and Fig. 8). The insertion of a custom-made teat tube with scalp vein, feeding tube or infusion tubes are mandatory to prevent accidental obliteration of the teat canal during suturing, suture dehiscence and pain resulting from milking during the post-operative period. The owners were advised to milk the animal twice daily by connecting syringe to the test tube. The teat tube was left in place for a maximum of three days and then replaced with another sterile tube.

The chances of self-mutilation and suture dehiscence can be further prevented by the use of tailored cloth cover for the udder which was used in the case IV with suture dehiscence due to self-mutilation by the doe. The time for healing varied between 12 to 15 days depending on the depth and extend of wound and the tissues involved and presence and absence of infection or self-mutilation.

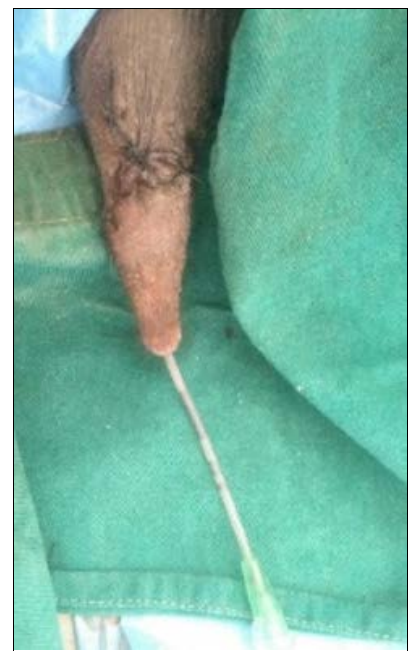

Fig 2: Post-operative appearance of the teat fistula in case I

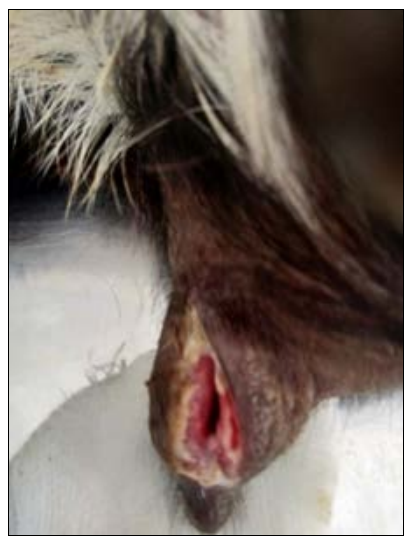

Fig 3: Pre-operative appearance of the teat fistula in case II

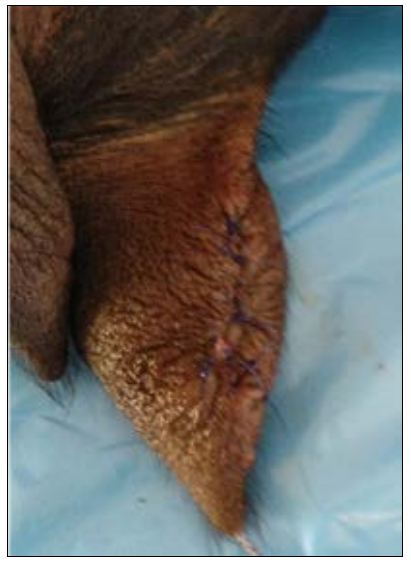

Fig 4: Post-operative appearance of the teat fistula in case II 


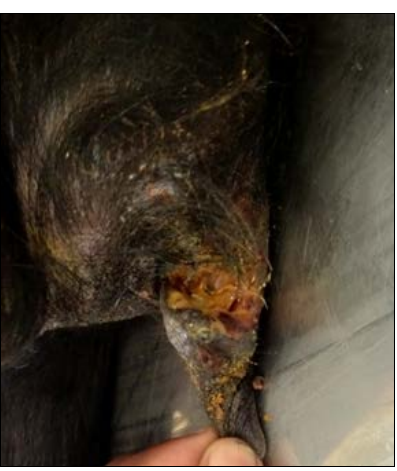

Fig 5: Pre-operative appearance of the teat fistula in case III

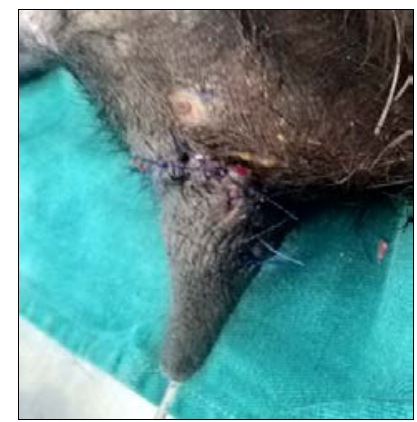

Fig 6: Post-operative appearance of the teat in case III

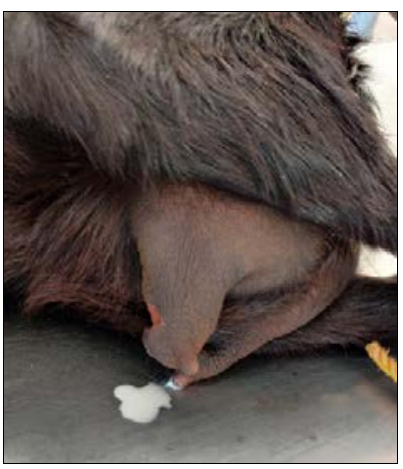

Fig 7: Pre-operative appearance of the teat fistula in case IV

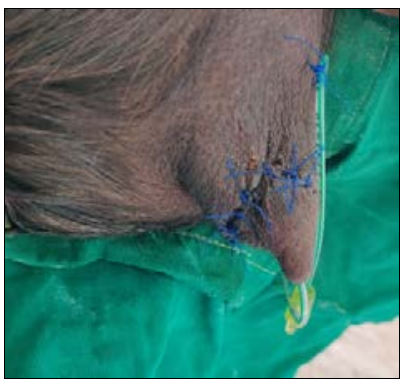

Fig 8: Post-operative appearance of the teat in case IV

\section{Conclusion}

The successful repair of teat fistula in four does is reported with emphasis on the precautions to be taken and the surgical management is explained in detail.

\section{Acknowledgement}

The authors are thankful to the Dean, Veterinary College and Research Institute Tirunelveli, for the encouragement and support. Thanks are due to the Director of Clinics, TANUVAS and Professor and Head, VCC, VCRI, Tirunelveli for the help received.

\section{References}

1. Angelo SJ, Dhar, S. Surgical repair of milk fistula in goat. The Indian Veterinary Journal 1971;48(4):419.

2. Chakrabarti A, Chandran PC, Kumar P, Dey A. Teat and udder disorders in goats (Capra hircus) in Bihar, India. South Asian Journal of Life Sciences 2014;2(2):20-22.

3. Ducharme NG, Arighi M, Horney FD, Livesey MA, Hurtig $\mathrm{MH}$, Pennock P. Invasive teat surgery in dairy cattle. Part I - Surgical procedures and classification of lesions. Canadian Veterinary Journal 1987;28(12):757762.

4. George LW, Divers TJ, Ducharme N, Welcome FL. Rebhun's diseases of dairy cattle. Edn. 2, Saunders Elsevier, St. Louis 2008;1:327-394.

5. Kashyap DK, Giri DK, Dewangan G. Teat fistula in a Jamunapari goat - A case report. Explorative Animal Medicine Research 2017;7(2):230-231.

6. Nichols S. Teat laceration repair in cattle. Veterinary Clinics of North America Food Animal Practice 2008;24(2):295-305.

7. Premsairam C, Aruljothi N, Balagopalan TP, Alphonse RMD, Abhiramy P. Surgical management of traumatic teat fistulas with polyester sutures in crossbred cows. IOSR Journal of Agriculture and Veterinary Science 2020;13(3):51-55.

8. Roberts J, Fishwick J. Teat surgery in dairy cattle. In Practice 2010;32(8):388-396.

9. Simon SM, Pushkin R, Sooryadas S, Sivashanker R, Rao GD, Justin WD. Traumatic fistulation of teat in a cow and its surgical management. Journal of Remount Veterinary Corps 2010;49:25-28.

10. Velavan A, Selvaraj P, Rajasundaram RC. Surgical repair of recurrent teat fistula using sutures and tissue adhesive in a cow - A case report. International journal of Food Agriculture and Veterinary Sciences 2014;4(1):152-154. 